\title{
EDUCATIVE NON-PRIVATIVE MEASURES OF FREEDOM
}

\author{
Raul-Teodor Zau Student \\ Vasile Goldiș Western University of Arad
}

(Received March 2017; Accepted June 2017)

\begin{abstract}
Infractionality or criminality in minor rank, even if it is a component of a general infractional phenomenon, it shows some particularities determined by biological, psychological and social characteristics of minor persons which Romanian legislature had in mind when it had foreseen their criminal liability. For this, The New riminal Code, stipulates some regulations on the educational measures regarding non privacy of freedom three conditions from the file - Recommandations R nr. 16/1992 of the European Committee. Measures regarding the non privacy of freedom are sanctions applied by the court and the young defendant is still in the society with some obligations on his side or institution which was bound by the court in the name of the law. The issue of this measure is to educate and reeducate the minor person who commited a crime, to ensure a change in his conscience to respect social values.
\end{abstract}

Keywords: minors, reeducation, educational measures, probation service, criminal offence of minors, discernment.

\section{Introduction}

From the analysis of the norms that regulated the minority in the 1969 Criminal Code, it can be noticed that the legislator treated it not as a state of attenuation of punishment, but as an institution with its own specific sanctioning regime (Antoniu, 2011). The crime phenomenon or juvenile delinquency, although part of the criminal phenomenon in general, has some peculiarities, determined by certain biological, psychological and social characteristics of minors, particularities which the legislator considered when regulating liability of Criminal proceedings (Antoniu, 2011). As it is emphasized in the literature, although the life of each person has in a specific way a specific development, it does not exclude the possibility that at the conceptual level, in the regulation of some criminal law institutions a common terminology of some concepts may be adopted, for example by borrowing from the private division of minor and major persons and use of the term minority.

In the criminal doctrine, it is also appreciated that juvenile deeds are considered to have a lower social danger than when committed by the minor, which is why the minority status is a cause of differentiation of criminal responsibility, hence the sanctioning regime, emphasizing it on prevention, both pre tort liability and post tort liability (Dongoroz, 2000).

In this respect, the new criminal law does not differ from the 1969 Criminal Code. Just like this code, it is admitted that until the age of 14 , the minor is presumed to 
have no discernment, this being an absolute presumption, and as such Will not be criminally liable.

This means that the minor up to the age of 14 is presumed, in all cases, to have no capacity to understand the social significance of his deeds, or to consciously manifest his will, a presumption that is absolute (iuris et de iure) in the sense that it is not permissible in any case to prove otherwise (Basarab, 1983). Between 14-16 years, the juvenile will only be criminally liable if it is proved that he committed the act with discernment. At this stage, the minor's lack of discernment is relative (iuris tantum), being allowed to be proven otherwise.The existence or nonexistence of discernment is usually done through a psychiatric expertise, corroborated with other evidence. If the minor aged 14-16 years has committed several acts under the criminal law for which he is to be held accountable, the discernment must be determined in relation to each individual deed.

After the age of 16, the minor is presumed to have acted with discernment and therefore be criminally liable; This means that the minor is presumed to be able to understand the social implications of his deeds and is able to conduct his behavior consciously; The presumption is relative in nature, because it can be proved to the contrary, in the sense that he/she did not have the capacity to understand the meaning of the deed and the ability to manifest his/her will for understanding the meaning of the deed (Basarab, 1983).

The lack of capacity to understand and the will arises from the way of committing the act, from the minor's antecedents, from the state of health, but also from a forensic expertise, which can establish in every case under investigation the existence or non-existence of discernment. The existence of discernment in committing an act provided by criminal law does not mean the existence of guilt, but only a precondition for it.

It is unanimously considered that the two states - age and discernment - must be taken into account in relation to the date when the offense was committed. In the literature it is considered that when part of the actions / inactions belonging to a continuous crime were committed during the juvenile years, without discernment, and the rest of the actions / inactions with discernment, the juvenile will answer only for the committed acts of discernment. If the action or inaction is continued after the age of 18 , the juvenile will respond in relation to the continuing crime in its entirety (Mitrache, 2006).

\section{Educative non-privative measures of freedom}

Non-custodial educational measures, according to the principle of the best interests of the child stated in the Council of Europe Recommendation no. 2008/11, is carried out in the community, under the supervision and control of probation services during their execution ensuring the maintenance and strengthening of the 
minor's ties with the family and the community, the free development of the personality of the minor, as well as his / her involvement in the programs, his / her formation of a spirit of responsibility and respect for the rights and freedoms of others (L. 253/2013, art. 63, alin. 1).

By the new regulation, namely the way in which it has been stated about the regime of non-custodial educational measures, all three conditions laid down in the Glossary of Recommendation R no. 16/1992 of the European Commission: noncustodial educational measures are penalties imposed by the court, by applying them the offender is maintained in the society, and certain obligations may be imposed, according to which the person or institution charged by the court is responsible under the law (Dascal, 2015).

As stipulated by the definition of the concept of sanction or Community measure in the glossary mentioned above, the essential aspect of defining a Community sanction is precisely its execution in an open environment rather than a prison. In this way the offender is punished for the act committed, while avoiding the negative effects of punishment execution in a carceral settlement. Thus, the offender remains in the family, can keep his job or continue his studies, but during this time his freedom of movement or action is restricted in order to limit the risk of relapse (Dascal, 2011).

Rule 23 of Recommendation R 16/1992 refers to the nature, content or method of implementing the community sanction that should not harm or condone the victim's privacy or dignity, recommending that self-respect. Family and community ties should not be endangered by the application of any community sanctions or measures.

Rules 30, 31 and 32 refer to the community's efforts to cultivate the perpetrator's sense of responsibility towards the community and the victim, in particular a sanction or community measure not to be ordered unless the conditions or obligations appropriate to the offender's profile are known and when Is prepared to cooperate to comply with imposed conditions or obligations (Dascal, 2011).

\subsection{The civic training course}

According to the provisions of art. 117 par. (1) of the Criminal Code, the civic training course is an educational measure consisting of the obligation for the minor to take part in a program of up to 4 months to help him understand the legal and social consequences he is exposed to in the case of committing crimes and to make him accountable for his future behavior.

The law provides only the maximum duration, thst is, the measure of 4 months, which means that the measure can be taken at any time of 4 months or less by taking into account the motivated proposals made by the probation counselor through the assessment report (Dascal, 2015). 
The purpose of this measure is to help the minor to observe the legal and social consequences of new offenses, namely to be subjected to a more severe noncustodial educational measure, or even a deprivation of liberty to his future behavior (Dascal, 2015).

The civic training course is organized in the form of continuous or periodic sessions lasting no more than 4 months and includes one or more theoretical or applicative modules adapted to the age and personality of the minor included in the scheme and taking into account if possible, the nature of the offense committed (Dascal, 2015).

- A monthly number of 8 hours of civic education will be considered in the course set by the court;

- The probation counselor in the probation service in whose circumscription the minor who attends the civic training course is, decides on the basis of the initial assessment of the minor, the institution in the community in which it is to take place, communicating to this institution the copy of the decision, as well as its decision;

- The designated community institution or probation service, as the case may be, adapts the concrete content of the traineeship according to the peculiarities of the juvenile, with the approval of the probation council;

- The conduct of the civic training course is carried out by a representative of the community institution established by the probation counselor's decision.

\subsection{Supervision}

According to the provisions of art. 118 of the Penal Code, the educational measure of supervision consists in controlling and guiding the minor in his daily program, between two and six months, under the coordination of the probation service, to ensure participation in school or vocational training courses and to prevent the deployment activities, or getting in touch with certain people who may affect their straightening process.

The educational measure of supervision can be taken for a period of between 2 and 6 months, with the purpose of ensuring the participation of the minor in school or vocational training and the prevention of activities or coming into contact with certain persons who may affect the process of rectificating it (Dascal, 2015).

Supervision and guidance of the minor in the execution of the educational measure of supervision is carried out by the parents of the minor, the adopters or the guardian. If they can not provide satisfactory supervision, the court orders the custody of the juvenile during the same time period for a person who is preferably a close relative of the minor at his request (L. 253/2013, art. 67, alin. 2).

The measure may be taken by the court for committing a single offense or for committing more than one offense in the contest irrespective of the number of 
offenses in the contest, to take only one educational measure, provided that the court considers that the measure is fit for the purpose if any of the offenses in the contest was committed after the age of 18 , the sanctioning rules provided for in art. 129, par. 2 of the Criminal Code (Dascal, 2015).

\subsection{Weekly signature}

According to the provisions of art. 118 The criminal code, the educational measure of the weekend record, consists in the obligation of the minor not to leave the dwelling on Saturdays and Sundays for a period between 4 and 12 weeks, unless during this period he has the obligation to participate in certain programs or carry out certain activities imposed by the court.

The prohibition imposed on the minor to leave the dwelling operates from 00.00 on Saturday and until 24.00 on Sunday (L. 253/2013, art. 68, alin. 2).

The measure has a precise content determined by the minor being obliged not TO leave the home on Saturdays and Sundays for a period of between 4 and 12 weeks in order to prevent him or her from being in certain places or to come into contact with certain people at this time of the week to avoid the possibility of committing other offenses (Dascal, 2015).

The measure may be taken by the court for committing a single offense or for committing more than one offense in the contest, irrespective of the number of offenses in the contest being taken only one educational measure, provided that the court considers that the measure is fit for the purpose, if any of the offenses in the contest was committed after the age of 18 years, the sanctioning rules provided for in art. 129 par. 2 of the Criminal Code (Dascal, 2015).

\subsection{Daily assistance}

According to the provisions of art. 119 The Criminal Code, the educational measure of daily assistance consists of the obligation of the minor to observe a program established by the probation service containing the timetable and the conditions for carrying out the activities, as well as the prohibitions imposed on the minor.

The educational measure of daily assistance is taken between 3 and 6 months, and the supervision of the execution of the educational measure is carried out by the probation counselor or, as the case may be, by the person designated by his / her decision within a community institution (L. 253/2013, art. 69, alin. 1).

- The daily schedule to be respected by the minor and the activities to be performed by him / her shall be agreed upon by the probation counselor and parents, guardian or other person in charge of the minor, in consultation with him / her;

- The established program will take into account the identified needs of the juvenile, his / her social situation and, where appropriate, the professional 
obligations and the obligations and prohibitions imposed on him / her during the execution of the measure;

- The daily schedule is established within 30 days from the moment the child is presented to the judge delegated with the execution.

The measure may be taken by the court for committing a single offense or for committing more offenses in the contest, irrespective of the number of offenses in the contest being taken only one educational measure, provided that the court considers that the measure is fit for the purpose if any of the offenses in the contest was committed after the age of 18 years, the sanctioning rules provided for in art. 129 par. 2 Penal Code (Dascal, 2015).

\section{The obligations that can be implied to the minor}

During the execution of any of the non-custodial educational measures, the court may impose on the minor the observance of one or more of the obligations stipulated in art. 121 Criminal Code (Dascal, 2015). These are:

- To attend a school or vocational training course;

- Not to exceed, without the consent of the probation service, the territorial limit established by the court;

- Not to be in certain places or at certain sports, cultural or other public gatherings established by the court;

- Not to approach or communicate with the victim or his / her family members, the participants in the offense or other persons established by the court;

- Submit to the probation service the data set by him / her;

- Subject to control, treatment or medical care.

\section{Modification or termination of obligations}

According to the provisions of art. 122 of the Penal Code if, during the course of the supervision, there are reasons that justify either imposing new obligations or increasing or diminishing the conditions of execution of the existing ones, the court may order the obligation to be modified accordingly in order to ensure the supervised person has better chances (Dascal, 2015).

Changing the obligations imposed by the court, either by increasing or reducing the conditions of execution, occurs when, depending on whether or not the minor complies with the obligations, makes or does not make progress for re-education, it is considered necessary to change them (Dascal, 2015).

The court has ordered the cessation of some of the obligations it has imposed when it considers that their maintenance is no longer necessary. 
Educative non-privative measures of freedom

\section{Conclusions}

Educational measures in criminal law are the consequences of criminal liability and are taken only in respect of minors who have committed an offense.

The purpose of educational measures is to educate and raise the juvenile who committed an offense to ensure a change in his conscience for respecting social values.

Educational non-custodial measures are: civic training; supervision; end of week record; daily assistance.

\section{Bibliography}

1. Antoniu, G., Vlășceanu A., Teodorescu, V., Sima, C., Ristea, I., Boroi, Al., Bulai, B.N., Daneș, ș.a, Explicații preliminare ale Noului Cod penal, vol II, Editura Universul Juridic, București, 2011;

2. Basarab, Matei, Drept penal-partea generală, Editura Didactică şi Pedagogică, București, 1983;

3. Dascăl, Teodor, Drept penal-Partea generală, Editura Casa Cărții de Știință, ClujNapoca, 2015;

4. Dascăl, Teodor, Minoritatea în dreptul penal român, Editura C.H.Beck, București, 2011

5. Dongoroz, V., Drept penal, Asociația Română de Științe Penale, București, 2000;

6. Mitrache, C., Drept penal român, Partea generală, Editura Universul Juridic, București, 2006;

7. *** Codul penal român;

8. *** Legea $n r .253 / 2013$; 